\title{
Effects of habitat complexity on Caribbean marine fish assemblages
}

\author{
Brian Gratwicke $^{1,2, *}$, Martin R. Speight ${ }^{1}$ \\ ${ }^{1}$ Department of Zoology, Oxford University, South Parks Road, Oxford OX1 3JA, UK
}

${ }^{2}$ Present address: The National Fish and Wildlife Foundation, 1120 Connecticut Avenue, NW, Suite 900, Washington, DC 20036, USA

\begin{abstract}
Sets of artificial reefs were replicated in 5 bays off Tortola in the British Virgin Islands to investigate the effects of habitat complexity on fish assemblages. Increasing percentage hard substrate and the number of small reef holes increased fish abundance on reefs. The observed number of species $\left(\mathrm{S}_{\mathrm{obs}}\right)$ occurring on each reef increased with increasing rugosity, variety of growth forms, percentage hard substrate, and variety of refuge hole sizes. A rarefied or abundance-corrected species richness measure $\left(\mathrm{S}_{\text {rare }}\right)$ was calculated to take the varying fish abundances into account. After this correction, rugosity was the only variable that significantly increased fish species-richness. Experimental reefs of different height $(20$ and $60 \mathrm{~cm})$ did not have significantly different fish abundance or species richness. The presence of long-spined sea urchins Diadema antillarum increased $\mathrm{S}_{\mathrm{obs}}$ and total fish abundance on artificial rock-reefs and in seagrass beds, but the effect was most pronounced in seagrass beds where shelter was a strongly limiting factor. These results indicate that complex habitats or animals such as $D$. antillarum that provide shelter to fish are essential for maintaining fish biodiversity at local scales. The most important aspects of complexity are rugosity, hard substrate and small refuge holes. Artificial reefs may be used to mitigate habitat damage in impacted areas, and if management objectives are to increase local fish abundance and species richness, the reefs should provide a stable substrate where this is unavailable, have a rugose surface with many small refuge holes, and have a variety of growth forms.
\end{abstract}

KEY WORDS: Diadema antillarum $\cdot$ Artificial reefs $\cdot$ Refuge $\cdot$ Species richness $\cdot$ Rarefaction $\cdot$ Biodiversity

\section{INTRODUCTION}

It is well known that habitat complexity affects species abundance and richness in many taxa including fishes (Risk 1972, Gorman \& Karr 1978, Luckhurst \& Luckhurst 1978, Roberts \& Ormond 1987, Gorham \& Alevizon 1989, McClanahan 1994, Caley \& St John 1996, Beukers \& Jones 1997, Horan et al. 2000, Ferreira et al. 2001, Harding \& Mann 2001), birds (MacArthur \& MacArthur 1961, Finch 1989, Telleria \& Carrascal 1994), lizards (Pianka 1966, 1973), mammals (Dueser \& Brown 1980, August 1983, Williams et al. 2002), insects (Southwood et al. 1979, Haslett 1997, Davidowitz \& Rosenzweig 1998), aquatic invertebrates (Heck \& Wetstone 1977, Gilinsky 1984), gastropods (Kohn 1967, Beck 2000) and ostracods (Hull 1997). The issue of habitat complexity is approached intuitively by most investigators, and even though there is a consensus that more complex habitats support a greater variety species, its quantification remains difficult. The word 'complexity' itself implies that many different measures of both the physical structure and the composition of habitat are required to assess it. This is further complicated by the fact that these variables are likely to have non-linear effects on the fish assemblage.

Other studies of habitat complexity and fish assemblages have tackled the issue in several different ways. Most are descriptive, correlating 1 or more measurements of complexity with fish species richness or abundance (e.g. Risk 1972, Gorman \& Karr 1978, Luckhurst \& Luckhurst 1978, Roberts \& Ormond 1987, Gorham \& Alevizon 1989, McClanahan 1994, Caley \& St John 1996, Beukers \& Jones 1997, Horan et al. 2000, Ferreira et al. 2001, Harding 2003). These approaches are com- 
plimented by artificial reef experiments that manipulate habitat in order to assess their effect on fish communities. These have ranged from documenting changes in fish assemblages around artificial reefs using the surrounding habitats as controls (e.g. Diamant et al. 1986, Bortone et al. 1988, Santos \& Monteiro 1998, Heise \& Bortone 1999, Freitas \& Petere 2001) to comparing fish assemblages on reefs with different profiles, volumes, numbers of holes or streamers (e.g. Molles 1978, Beets 1989, Gorham \& Alevizon 1989, Borntrager \& Farrell 1992, Hixon \& Beets 1993, Caley \& St John 1996, Kellison \& Sedberry 1998, Rilov \& Benayahu 2002).

While these independent studies have been very informative, there is no satisfactory way to synthesise all the findings in a meaningful way because they were carried out in different geographical locations and used varying methods, making direct comparisons between the different treatments impossible. Thus, a systematic approach that simultaneously examines as many complexity variables as possible to determine which are the most important factors is needed. For this study, 5 main habitat-complexity variables recurring in the literature were identified: (1) topographic complexity or rugosity of the substrate (Risk 1972, Luckhurst \& Luckhurst 1978, Roberts \& Ormond 1987, Jennings et al. 1996, Chabanet et al. 1997, Ohman \& Rajasuriya 1998), (2) substratum diversity (Roberts \& Ormond 1987, Ohman \& Rajasuriya 1998), (3) variety of refuge hole sizes (Roberts \& Ormond 1987), (4) vertical relief or height of substrate architecture (Luckhurst \& Luckhurst 1978, Molles 1978) and (5) percentage hard substrate (Cohen et al. 1993, Guidetti 2000, Khalaf \& Kochzius 2002). The

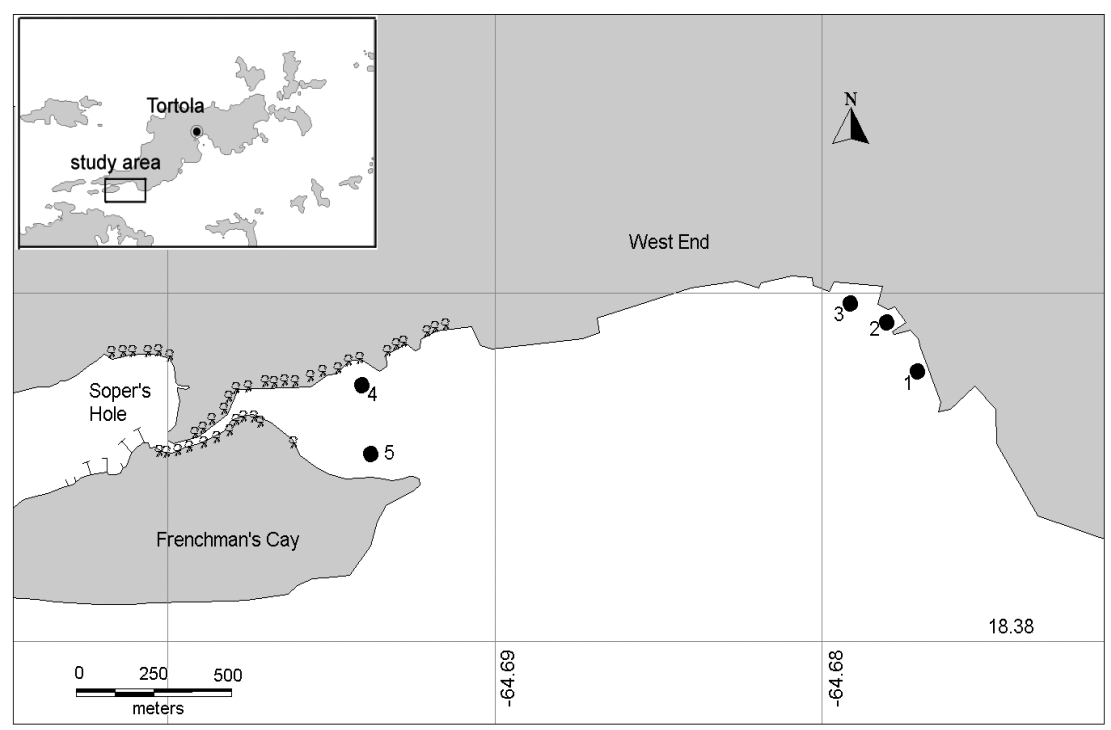

Fig. 1. Location of 5 sites where each of 15 experimental reefs were located off Tortola, British Virgin Islands effects of each of these variables on the local fish assemblage were tested in a field experiment, and this study is one of the first experimental attempts to simultaneously compare the effects of all these habitat complexity variables. In addition, field observations suggested that long-spined sea urchins Diadema antillarum might increase the number of fishes/species by providing shelter in low-complexity environments and this was also investigated.

\section{MATERIALS AND METHODS}

Study area. Artificial reefs were positioned in 5 different stations situated in sparse seagrass on the south shore of Tortola (Fig. 1). The stations were all within $500 \mathrm{~m}$ of a fringing reef but were varying distances from mangroves that are potential sources of fish recruits (Fig. 1); thus the 5 stations were treated as blocks in the experimental design. The reefs were situated in areas unfrequented by tourists and with no obvious sources of disturbance to the fish community apart from occasional Antillean fish traps set by local fishermen; 6 to 10 traps were usually present in the study area, but traps were never closer than $200 \mathrm{~m}$ to the artificial reefs. Turtlegrass Thalassia testudinum covered about $60 \%$ of the substrate in the immediate vicinity of all the artificial reefs, and the most abundant macroinvertebrates were short-spined urchins known as sea eggs Tripneustes ventricosus and long-spined sea urchins Diadema antillarum. Small octopi Octopus vulgaris and spiny lobsters Panulirus argus were the most commonly encountered macroinvertebrates on the artificial reefs.

Habitat complexity. Experimental reefs and plots were replicated once at each of the 5 stations that served as blocks in a randomised block design. At each station the different designs were laid out in a grid pattern with $10 \mathrm{~m}$ between each reef. The relative position of the experimental unit in each grid was randomly assigned and the following hypotheses were investigated:

Increasing rugosity increases fish species richness/abundance (Hypothesis 1): A flat $1 \mathrm{~m}^{2}$ concrete reef served as the control; it was constructed using a $1 \mathrm{~m}^{2}$ wooden base made from wooden planks, which was covered with a $3 \mathrm{~cm}$ layer of concrete giving a total surface area of $1 \mathrm{~m}^{2}$ (Fig. 2: Reef 1). The first treatment con- 
sisted of 6 concrete blocks, $40 \times 20 \times 15 \mathrm{~cm}$, without holes, arranged on a $1 \mathrm{~m}^{2}$ concrete base with a total surface area of $2.32 \mathrm{~m}^{2}$ (Fig 2: Reef 2). The second treatment increased the rugosity by using 6 stacks that were each 2 blocks high, with a total surface area of $3.64 \mathrm{~m}^{2}$ (Fig. 2: Reef 3); 1 reef of each design was present at each station. Rugosity is often expressed as the ratio of actual surface area in relation to linear surface area (quadrat size) (Luckhurst \& Luckhurst 1978). Thus the rugosity ratios for the reefs are 1.0 (control), 2.32 (1-block stacks), and 3.64 (2-block stacks).

Taller reefs have higher fish species richness/abundance than short reefs (Hypothesis 2): We used 2 artificial reefs to test this hypothesis. A short reef served as control. It was constructed of 6 concrete blocks, without holes, measuring $40 \times 20 \times 20 \mathrm{~cm}$; the blocks were
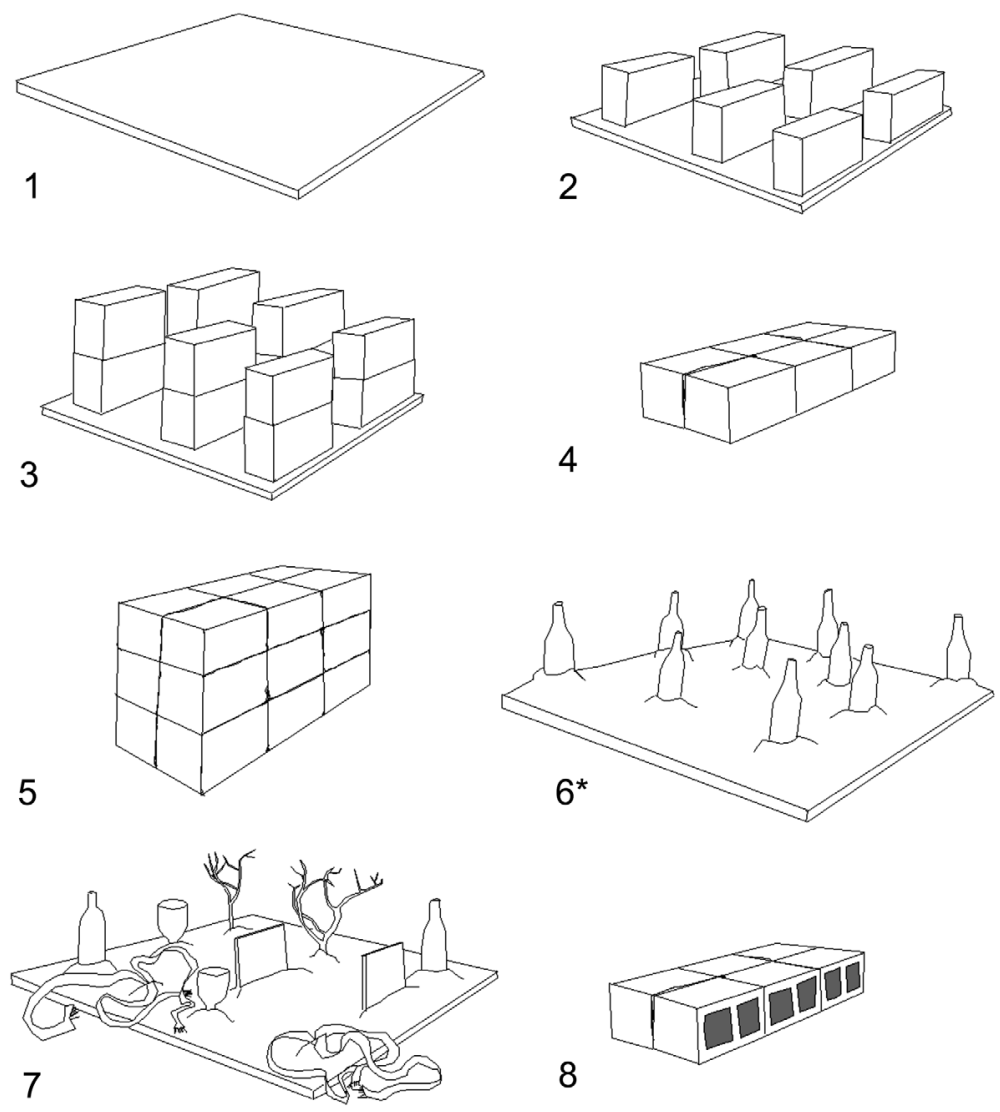

8

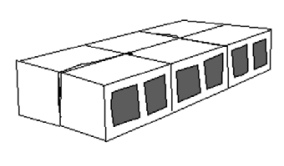

9
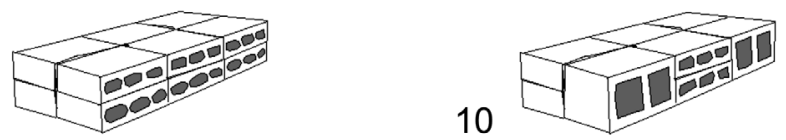

Fig. 2. Artificial reefs used to test 5 habitat-complexity hypotheses; 1 of each design was established at each of the 5 sites. Reef 1 is $1 \mathrm{~m}^{2}$ (to give idea of scale). *In Reef 6, each replicate had 1 different growth form (all 5 forms shown for Reef 7). For full descriptions of reef forms see 'Materials and methods' packed tightly together in a single layer (Fig. 2: Reef 4). The second, tall, reef was similar, but piled 3 layers high (Fig. 2: Reef 5); 1 reef of each design was present at each station.

Increased variety of growth forms increases fish species richness/abundance (Hypothesis 3): A flat, $1 \mathrm{~m}^{2}$ concrete reef with no growth forms served as the control in this experiment, and 1 flat reef (Fig. 2: Reef 1) was present at each station. The first treatment (1 growth form) consisted of 5 replicates: 1 reef was built with 10 glass bottles embedded in it (cylindrical growth form) and was placed at Stn 1 (Fig. 2: Reef 6); 1 reef had 10 plastic bottles with the bottoms sawn off (tubular growth form) and was placed at Stn 2; 1 reef had 10 small tree branches (branching growth form) and was placed at Stn 3; 1 reef with 10 upright tiles (plate-like growth form) and was placed at Stn 4; the last reef had 10 canvas strips (filamentous growth form) and was placed at Stn 5. It might be argued that the single growth-form reefs are not true replicates as each of the 5 units differs from the others. However, this hypothesis requires that there is only 1 kind of growth form present, and the actual type of growth form is irrelevant. The second treatment ( 5 growth forms) used all 5 growth forms. Each growth form was represented twice on each reef and their relative positions were randomly assigned (Fig. 2: Reef 7).

Increased variety of hole sizes increases fish species richness/abundance (Hypothesis 4): We packed 6 concrete blocks, without holes, measuring $40 \times 20 \times 20 \mathrm{~cm}$, tightly together in 1 layer to form the control reef (no holes) (Fig. 2: Reef 4). A similar arrangement of blocks with large, $13 \times 13 \mathrm{~cm}$ holes comprised the first treatment (large holes) (Fig. 2: Reef 8) and a similar arrangement of blocks with $4 \times 8 \mathrm{~cm}$ holes the second treatment (small holes) (Fig. 2: Reef 9). A reef consisting of both small and large holes was the final treatment (Fig. 2: Reef 10). There was 1 reef of each design at each station. There were fewer holes per unit volume in the large-holed structures (12) than in those with mixed-hole sizes (24); in turn, these had fewer holes than the small-holed (36) structures. (Note: Hixon \& Beets [1993] found that the number of holes was a limiting factor for fishes on artificial reefs with fewer than 12 holes, but not for those on reefs with more than 12 holes.) The purpose of this experiment was to test the effect of variety of hole size, keeping the volume of the artificial reef 
constant, with the hypothesis predicting that the smalland large-holed reefs would have more species than any other design, regardless of the number of holes.

Increased percent hard substrate increases fish species richness/abundance (Hypothesis 5): The control ( $0 \%$ hard substrate) plots were selected from bare sandy patches occurring in the seagrass beds at each of the stations. Plots of $1 \mathrm{~m}^{2}$ were marked in the sand as permanent plots using steel pegs. In sandy areas, we created $50 \%$ percent hard substrate treatments by covering $50 \%$ of the substrate with $20 \times 20 \mathrm{~cm}$ terracotta tiles. The $1 \mathrm{~m}^{2}$ flat concrete reefs served as the $100 \%$ hard substrate treatment. In order to assess the relative effects of percentage hard substrate compared to the surrounding habitat type, a $1 \mathrm{~m}^{2}$ plot of seagrass was also examined. We set up 1 of these of these designs at each station. The hypothesis would technically predict that the seagrass plot should have the same number of fish/species as the sand plot but, because of the growth forms, Hypothesis 1 would actually expect the seagrass plot to have more fish/species than the sand plot.

Field sampling. Reefs were left for at least $1 \mathrm{wk}$ to enable a fish population to become established on each of the reefs or plots. Water depth varied between 1 and $5 \mathrm{~m}$ and mean visibility was $10 \mathrm{~m}$. A single observer (B. Gratwicke) performed the fish counts by snorkelling and counting all fish hiding in, under or located within $30 \mathrm{~cm}$ of each reef in a 5 min sampling period. Fishes were identified and counted, and then tallied on an underwater slate. Observations were initially made from a distance of about $1 \mathrm{~m}$ for the first $4 \mathrm{~min}$ and the last minute was spent actively searching for camouflaged fishes and those hiding in the structure. Each of the stations (Fig. 1) was assigned a regular sampling day (Monday to Friday) and was visited once a week for a period of $5 \mathrm{wk}$ between July and August 2002. At each station the individual reefs were visited in randomised order between 08:00 and 17:00 h each day.

Sea urchins. We built 10 rock-reefs by piling 10 to $20 \mathrm{~cm}$ diameter rocks to a height of about $40 \mathrm{~cm}$ with a base of $1 \mathrm{~m}^{2}$. They ranged between 1 and $3 \mathrm{~m}$ depth at Stns 1 and 2. We left 5 reefs bare, and placed 10 Diadema antillarum on each of the remaining 5 reefs. The sea urchins were left for a period of $1 \mathrm{wk}$, during which time the reefs were checked daily and urchin numbers were replenished if any had emigrated. After $1 \mathrm{wk}$, all fishes on the reefs were counted over a $5 \mathrm{~min}$ period. In surrounding seagrass beds (low-complexity environments), $1 \mathrm{~m}^{2}$ quadrats were laid over daytime urchin aggregations (ranging from 6 to 11 individuals); fishes were counted, and their numbers were compared with those in an adjacent seagrass quadrat $(5 \mathrm{~m}$ away) that did not have any urchins. The quadrat poles were left for about 10 min before counting the fishes to allow them to become accustomed to the poles and to the presence of the observer. The hypothesis predicts that if shelter were the limiting factor in the low-complexity seagrass beds, the presence of urchins would increase the numbers of fish/species. However, on high-complexity reefs where shelter is less of a limiting factor there would be less difference between numbers of fish/species on reefs with and without urchins.

Analysis. The data for each reef over the 5-sample period was pooled and analysed using SPSS Version $11.5^{\odot}$ software unless stated otherwise. While sampling effort was constant over all experimental units, the total sample size varied. One problem when comparing samples of different sizes is that larger samples would be expected by mere chance alone to have more species than smaller samples (Simberloff 1972, Caley \& St John 1996). The species richness of samples of different sizes can be made comparable by an abundance-correction process called rarefaction (Simberloff 1972). Rarefaction curves were calculated for each experiment and corrected for differences in abundance using Biodiversity Pro Software ${ }^{\odot}$ (Natural History Museum and Scottish Association for Marine Science). This programme randomly selects individuals from each sample and repeats a number of iterations to produce a plot of expected species richness against abundance so that the species richness of all samples can be compared at the same abundance levels.

All data were tested for normality (KolmogorovSmirnov test) and homogeneity of variance (Levene test) and square-root-transformed if necessary. Each hypothesis was analysed in turn using a randomised block design ANOVA analysis, blocked by bay to control for factors such as varying distances from other habitats such as coral reefs and mangroves that may have acted as potential sources of fish recruits. The hypothesis that the presence of sea urchins affected fish species richness and abundance on each habitat type was tested using a 2-way ANOVA.

\section{RESULTS}

We encountered 60 fish species from 27 different families on all 65 artificial reefs or plots during the 5 wk sampling period and a total of 7788 fishes were counted in all (Table 1). Fishes were rapidly attracted to the new structures. For example, during the construction of 1 rocky artificial reef on a fishless, sandy substrate, 7 different species were attracted to the site within 20 min. Many of the fishes attracted to the reefs were juveniles, particularly white grunts Haemulon plumieri, tomtates $H$. aurolineatum, yellowtail snappers Ocyurus chrysurus, and juvenile parrotfish Scarus spp. (Table 1). These small, numerically dominant fishes sheltered near the artificial reefs from roving 
Table 1. List of fish species and their abundance on artificial reefs

\begin{tabular}{|c|c|c|}
\hline Family & Species & Total no. \\
\hline Acanthuridae & $\begin{array}{l}\text { Acanthurus bahianus } \\
\text { A. chirurgus } \\
\text { A. coeruleus }\end{array}$ & $\begin{array}{r}183 \\
15 \\
31\end{array}$ \\
\hline Apogonidae & Apogon maculatus & 12 \\
\hline Aulostomidae & Aulostomus maculatus & 8 \\
\hline Belonidae & Tylosurus crocodilus & 3 \\
\hline Blenniidae & Parablennius marmoreus & 11 \\
\hline Bothidae & Bothus lunatus & 16 \\
\hline Carangidae & $\begin{array}{l}\text { Caranx latus } \\
\text { C. ruber }\end{array}$ & $\begin{array}{r}2 \\
28\end{array}$ \\
\hline Chaetodontidae & $\begin{array}{l}\text { Chaetodon capistratus } \\
\text { C. striatus }\end{array}$ & $\begin{array}{r}221 \\
1\end{array}$ \\
\hline Diodontidae & Diodon holacanthus & 6 \\
\hline Gerreidae & Gerres cinereus & 2 \\
\hline Gobiidae & $\begin{array}{l}\text { Coryphopterus dicrus } \\
\text { C. glaucofraenum } \\
\text { Gobionellus saepepallens } \\
\text { Gnatholepis thomsoni } \\
\text { Nes longus }\end{array}$ & $\begin{array}{r}3 \\
86 \\
1 \\
1 \\
2\end{array}$ \\
\hline Haemulidae & $\begin{array}{l}\text { Haemulon aurolineatum } \\
\text { H. carbonarium } \\
\text { H. flavolineatum } \\
\text { H. macrostoma } \\
\text { H. melanurum } \\
\text { H. parra } \\
\text { H. plumieri }\end{array}$ & $\begin{array}{r}1278 \\
1 \\
109 \\
2 \\
1 \\
3 \\
2229\end{array}$ \\
\hline Holocentridae & $\begin{array}{l}\text { Holocentrus adscensionis } \\
\text { H. coruscus } \\
\text { H. rufus }\end{array}$ & $\begin{array}{l}2 \\
5 \\
4\end{array}$ \\
\hline Labridae & $\begin{array}{l}\text { Halichoeres bivittatus } \\
\text { H. poeyi } \\
\text { H. radiatus } \\
\text { Thalassoma bifasciatum }\end{array}$ & $\begin{array}{r}498 \\
146 \\
10 \\
40\end{array}$ \\
\hline Labrisomidae & $\begin{array}{l}\text { Malacoctenus gilli } \\
\text { M. macropus/versicolor } \\
\text { M. triangulatus }\end{array}$ & $\begin{array}{r}1 \\
115 \\
1\end{array}$ \\
\hline Lutjanidae & $\begin{array}{l}\text { Lutjanus synagris } \\
\text { Ocyurus chrysurus }\end{array}$ & $\begin{array}{r}49 \\
1174\end{array}$ \\
\hline Monocanthidae & $\begin{array}{l}\text { Cantherhines pullus } \\
\text { Monacanthus ciliatus } \\
\text { M. tuckeri }\end{array}$ & $\begin{array}{l}8 \\
4 \\
3\end{array}$ \\
\hline Mullidae & $\begin{array}{l}\text { Mulloidichthys martinicus } \\
\text { Pseudupeneus maculatus }\end{array}$ & $\begin{array}{r}5 \\
21\end{array}$ \\
\hline Muraenidae & Gymnothorax vicinus & 13 \\
\hline Ophichthidae & Myrichthys ocellatus & 1 \\
\hline Ostraciidae & Lactophrys trigonus & 1 \\
\hline Pomacentridae & $\begin{array}{l}\text { Stegastes leucostictus } \\
\text { S. partitus }\end{array}$ & $\begin{array}{r}158 \\
2\end{array}$ \\
\hline Scaridae & $\begin{array}{l}\text { Sparisoma aurofrenatum } \\
\text { Scarus spp. }<10 \mathrm{~cm} \\
\text { Sparisoma radians } \\
\text { S. rubripinne } \\
\text { S. viride }\end{array}$ & $\begin{array}{r}23 \\
742 \\
299 \\
3 \\
18\end{array}$ \\
\hline Serranidae & $\begin{array}{l}\text { Alphestes afer } \\
\text { Hypoplectrus puella } \\
\text { H. unicolor }\end{array}$ & $\begin{array}{r}65 \\
105 \\
2\end{array}$ \\
\hline Sparidae & Calamus calamus & 1 \\
\hline Synodontidae & Synodus intermedius & 5 \\
\hline Tetraodontidae & Canthigaster rostrata & 7 \\
\hline $\mathrm{n}=27$ & $\begin{array}{l}\text { Sphoeroides spengleri } \\
\mathrm{n}=60\end{array}$ & $\begin{array}{r}2 \\
\mathrm{n}=7788\end{array}$ \\
\hline
\end{tabular}

predators such as the jacks Caranx ruber and C. latus, while other predators such as the purple mouth moray Gymnothorax vicinus and the mutton fish Alphestes afer quickly took up residence. After the first week the reefs were covered in a thin algal film but a substantial fouling community did not develop during the $5 \mathrm{wk}$ sampling programme-probably because of high grazing pressure from juvenile parrotfish and surgeonfish (B. Gratwicke pers. obs).

\section{Complexity hypotheses}

Increasing rugosity increases fish species richness/ abundance (Hypothesis 1). Rugose reefs had significantly higher observed $\left(\mathrm{S}_{\mathrm{obs}}\right)$ and abundancecorrected species richness $\left(\mathrm{S}_{\text {rare }}\right)$ than the flat reefs, but there was no significant difference between reefs with 2 block high stacks and the less rugose 1 block stacks. Increasing rugosity does not, therefore, increase fish species richness proportionally (Fig. 3). The total fish abundance was not significantly affected by changes in rugosity (Fig. 3).

Taller reefs have higher fish species richness/abundance than short reefs (Hypothesis 2). There was no significant effect of reef height on fish abundance, observed species richness or abundance-corrected species-richness (Fig. 3).

Increased variety of growth forms increases fish species richness/abundance (Hypothesis 3). Reefs with 5 growth forms had more species in total than the model with no growth form, and abundance-corrected speciesrichness estimates had a similar trend although it was not significant at the $\mathrm{p}=0.05$ level (Fig. 3). These results were broadly consistent with the hypothesis that increasing the number of growth forms increases species richness, but more replicates would have been desirable.

Increased variety of hole sizes increases fish species richness/abundance (Hypothesis 4). The small-holed reef had significantly higher numbers of fishes (about 270) than all the other designs (Fig. 3). However, the observed number of species was not significantly different between reefs without holes, small holes only, or large holes only. These unexpected results indicated that only 2 treatments were significantly different: large-holed treatment with an average of 12 fish species, and the mixed-hole treatment with about 16 species. The fact that the mixed-hole treatment had the most species was consistent with the initial hypothesis, but the lack of significant differences among the remaining reefs means that these results are inconclusive. More light would be shed on this hypothesis if the experiment were repeated, but keeping a constant number of holes in each reef design, as the variable hole numbers was a confounding influence in this experiment. 

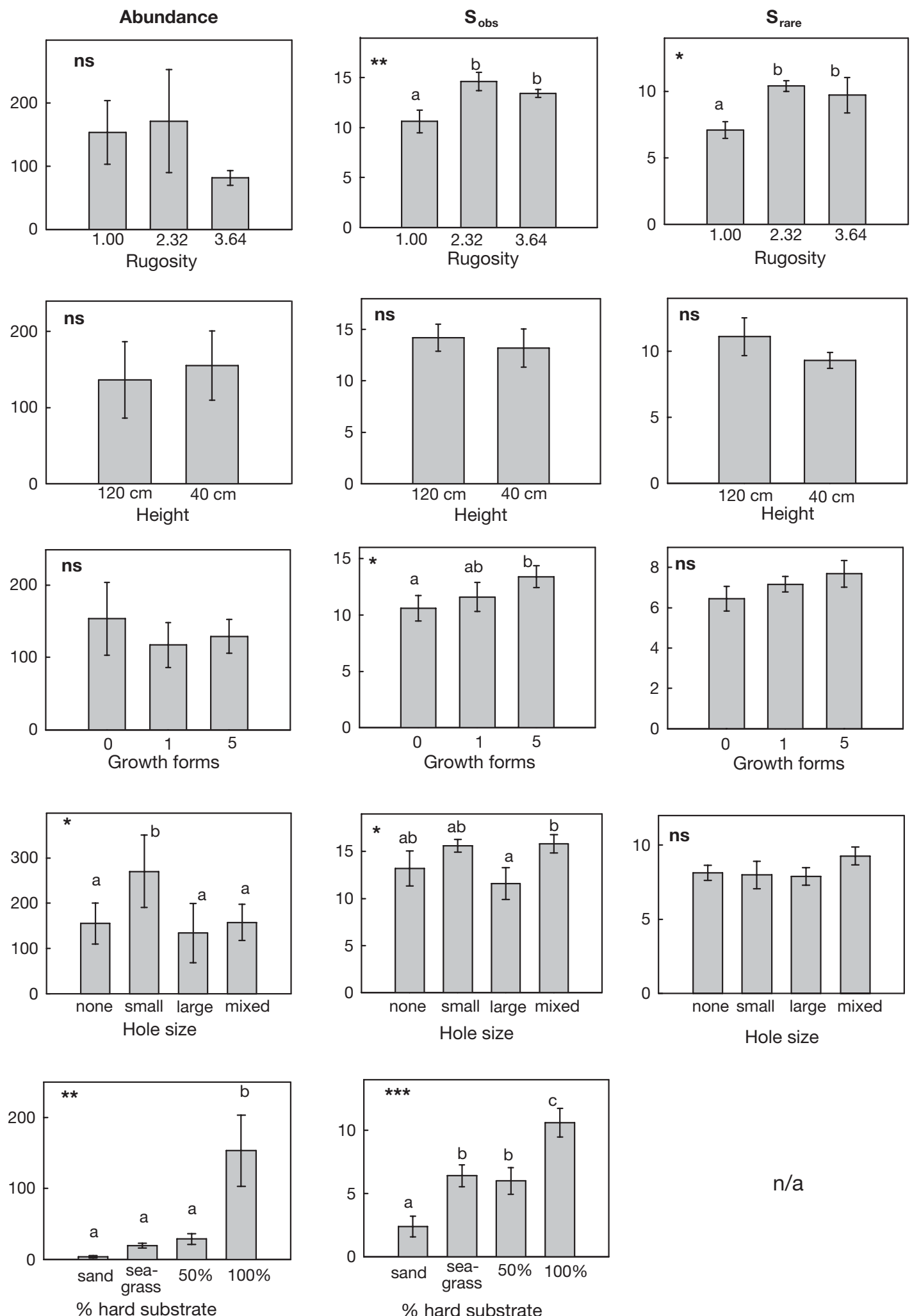

$\mathrm{n} / \mathrm{a}$

Fig. 3. Effects of 5 habitat complexity variables on mean $( \pm \mathrm{SE})$ total fish abundance, number of species $\left(\mathrm{S}_{\mathrm{obs}}\right)$ and abundancecorrected (rarefied) species richness $\left(\mathrm{S}_{\text {rare }}\right)$. Data were analysed using a randomised block ANOVA, to take into account differences between bays. There was no significant difference between means with identical letters (post hoc Tukey test). ns: not significant; n/a: not applicable. ${ }^{*} \mathrm{p}<0.05,{ }^{*}$ p $0.01,{ }^{* * *} \mathrm{p}<0.001$ 
Increased percent hard substrate increases fish species richness/abundance (Hypothesis 5). Fish species richness increased with increasing percentage hard substrate (Fig. 3). However, some of the sample sizes were so small (zero in some replicates) that rarefaction curves could not be calculated for expected numbers of species. Interestingly, the $1 \mathrm{~m}^{2}$ seagrass quadrat that had 1 growth form and no hard substrate was more stable than sand because the seagrass roots held it together, and had a similar number of fishes to the $50 \%$ hard substrate treatment.

\section{Urchins}

Diadema antillarum did significantly affect the diurnal fish community, largely by providing shelter for small fishes. A total of 56 different fish species were encountered in this experiment. The most common fish species sheltering among the urchins spines were Haemulon spp. Ocyurus chrysurus, Chaetodon capistratus, Halichoeres bivittatus and Acanthurus bahianus. The presence of urchins had a much stronger effect on fish species richness and abundance in the low-complexity seagrass beds than on high-complexity reefs (Fig. 4). Fish abundance in seagrass increased more than 6 -fold when $D$. antillarum were present, but on artificial reefs urchins doubled fish numbers. The number of fish species almost doubled in seagrass quadrats with urchins, but the difference was less pronounced on reefs.

\section{DISCUSSION}

This study has demonstrated that habitat complexity variables affect fish species richness and abundance in varying degrees, but these effects are difficult to separate because increasing abundance will increase the probability of encountering more species. Hard substrate and refuge holes were key factors influencing abundance, while $\mathrm{S}_{\text {obs }}$ was influenced by rugosity, hard substrate, holes, and variety of growth forms. After correcting the species data for abundance using rarefaction curves, rugosity was the only factor significantly affecting $\mathrm{S}_{\text {rare. }}$ It is also clear that the responses to each complexity variable are not necessarily linear and that they do vary in their degree of influence on the fish assemblage.

Total fish abundance on the reefs for all designs (except hard substrate) was consistently higher in some bays than in others. The effect is probably because of differing distances from habitats such as reefs or mangroves that are potential sources of fishes migrating to the artificial reefs, or because of different prevailing currents, which are sources of larval recruitment (Molles
1978, Ogden \& Gladfelter 1983, Valles 2001, Nagelkerken et al. 2002). Hole-size and percentage hard substrate were the only complexity variables that significantly affected total fish abundance. The small-holed reefs excluded larger predatory fishes such as jacks or the mutton hamlet Alphestes afer, and it was probably this increase in predator-free space that allowed higher numbers of fishes to live on small-holed reefs; similar results have been found in other experiments (Molles 1978, Hixon \& Beets 1993, Caley \& St John 1996).

Increasing the proportion of hard substrate does not offer increased refuge space to fishes; instead hard substrates act as a fixed point of attachment-which is one of the most limiting factors in a marine environment-particularly in the photic zone (Dahl 1973). Hard substrates are often covered in a thin film of periphyton that is an important food resource to grazing animals, and this periphyton is responsible for much of the total primary production in these marine systems. Theoretically, increasing the total hard surface area of a reef will increase its net productivity and hence increase the total number of fishes it can support; this explains the observed pattern, which has also been

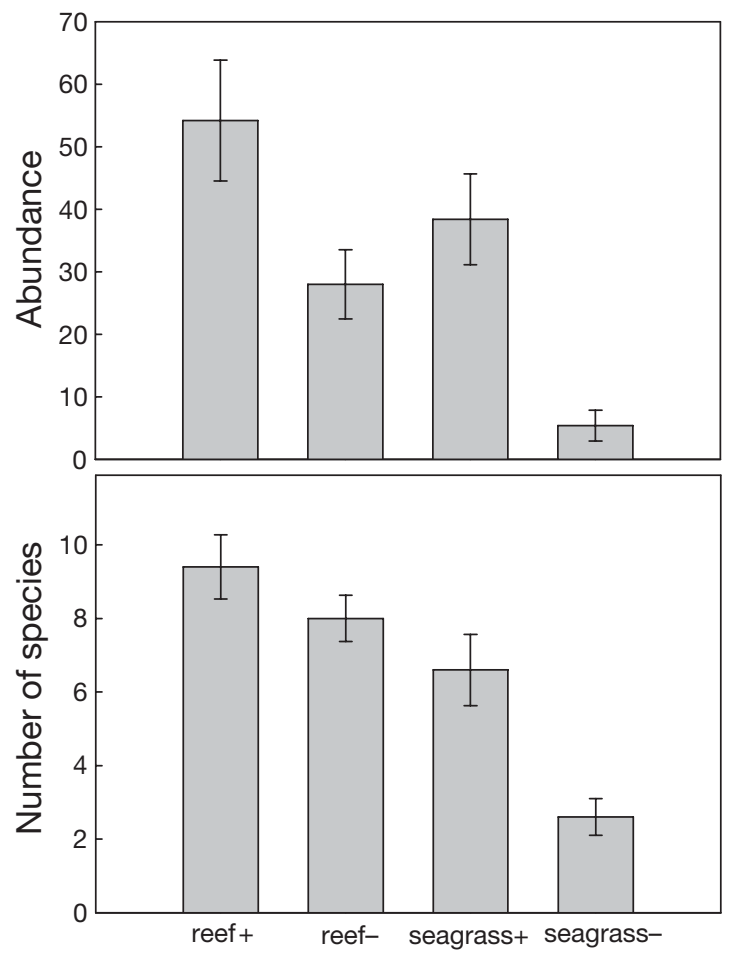

Fig. 4. Comparison of differences in fish species richness and abundance on reefs and seagrass plots with urchins (+) compared to those without urchins (-). A 2-way ANOVA indicated that presence of urchins strongly affected fish abundance $(p<0.001)$ and observed species richness $(p<0.004)$, while habitat had highly significant effect on fish abundance $(p<0.01)$ and observed species richness $(p<0.001)$ 
documented in the Red Sea (Khalaf \& Kochzius 2002). The presence of seagrass in a quadrat might have a similar effect, because the seagrass leaves offer a stable surface for periphyton growth, as well as limited refuge from predators.

All the complexity variables (except reef height) significantly affected the total number of fish species attracted to the reefs, as broadly predicted by the initial hypotheses. However, other investigators working with artificial reefs have argued that any observed increases in species richness are artifacts of the main effect-increasing fish abundance (Molles 1978, Caley \& St John 1996). This factor was taken into account by calculating rarefaction curves to give an abundancecorrected species-richness measure. While many of the trends were similar before and after rarefaction, rugosity was the only factor affecting both $\mathrm{S}_{\mathrm{obs}}$ and $\mathrm{S}_{\text {rare }}$. The rarefaction process reduced overall sample sizes quite substantially (as comparisons for each hypothesis can only be made at the abundance level of the smallest sample), and this probably inflates the risk of Type II error; thus the $\mathrm{S}_{\text {rare }}$ results are conservative.

Rugosity was a significant complexity variable, even after rarefaction, making it one of the most important factors affecting fish species richness. Many field studies have described positive correlations between fish species richness and substrate rugosity (e.g. Risk 1972, Luckhurst \& Luckhurst 1978), but this is the first experimental test of this hypothesis. Possible explanations for the increased number of fishes in rugose areas include increased refuge from predators or increased primary productivity on the hard surfaces that can support more fishes. Increasing the size of the stacks did not have any significant effect on fish species richness. Thus predator avoidance is probably more important than total hard surface area. If this is true, then increasing the number of the stacks would probably have a more positive effect than increasing their height.

Counting the variety of growth forms present in a quadrat is an assessment of the habitat heterogeneity in that area; it can be used in a range of different habitat types without having to identify individual species of algae sponges or corals. Even though the growth forms used in this experiment did not offer a range of different potential food resources (as might have been the case with living growth forms), the mere presence of a variety of different shapes was enough to significantly increase the observed numbers of species on the artificial reefs, probably by increasing the variety of niches on the reef. For example, small grunts Haemulon spp. used the filamentous canvas strips to hide from predators, while damselfish Stegastes leucostictus preferred the hollow cups as nesting sites, and the trumpetfish Aulostomus maculatus preferred branching growth forms because they stalk their prey using the branches to camouflage their long, thin body (B. Gratwicke pers. obs). While no other studies have related fish species richness to the variety of growth forms per se, fish species richness has previously been correlated with the diversity of substratum variables (Roberts \& Ormond 1987) and with the number of different habitat categories (Ohman \& Rajasuriya 1998).

Luckhurst \& Luckhurst (1978) suggested that reefs with a variety of hole sizes would offer shelter to species across a range of body sizes, and that this would increase available niche space and number of species. In our experiment, the reef design with a variety of hole sizes did have an abundance-corrected average of 2 more species than any of the other designs, but this difference was not significant at the $p=0.05$ level. This experiment did have some confounding influences such as varying numbers of holes and small sample sizes after rarefaction, so these results are inconclusive and more work in this area would be informative.

Taller reefs are likely to have larger stable surface areas than shorter reefs (Dahl 1973), or they may simply be more conspicuous in the water column and hence more effective at aggregating pelagic fishes and larvae. This is the principle behind fish aggregating devices. In the Red Sea for example, the vertical height of jetty pillars was correlated with fish species richness and abundance, but they ranged from 1 to $20 \mathrm{~m}$ (Rilov \& Benayahu 1998). In our experiment there were no significant differences in abundance or observed or expected number of species between $20 \mathrm{~cm}$ high and $60 \mathrm{~cm}$ high reefs. The discrepancies with other studies (e.g. Molles 1978, Kellison \& Sedberry 1998, Rilov \& Benayahu 2002) may be explained by 1 or more of the following reasons: (1) vertical profile does have an important effect on the fish community of a reef, but the differences in height tested in our experiment were not sufficient to detect a significant effect, (2) sample sizes $(n=5)$ were not sufficient to statistically distinguish weak differences between the reefs, (3) height differences detected in the other studies were due to some other variable such as increased refuge availability on taller reefs, and this was incidentally correlated with the vertical profile of the reef.

Long-spined urchins Diadema antillarum also enhanced fish species richness and abundance, particularly in low-complexity habitats, showing that the effects of habitat complexity are not limited to fixed structural features on the substrate. Similar commensal relationships between species are quite common in marine environments; for example the pearlfish Carapus bermudensis shelters in the anus of sea cucumbers during the day and forages in seagrass beds at night, and the remora Remora remora attaches to large free-swimming fishes such as sharks (Humann 1994). Urchins, however, have not really been considered an important factor for fishes 
and most previous fish-urchin studies have been in the context of competitive grazing interactions between urchins and herbivorous fishes (e.g. Randall 1965, Foster 1985, Hay \& Taylor 1985, Carpenter 1986, 1990, Robertson 1991). Only a few studies have examined the positive effects of urchins on fish diversity (Randall et al. 1964, Magnus 1967, Hartney \& Grorud 2002); thus increasing urchin populations will reduce the carrying capacity of herbivorous fishes, but will simultaneously increase survivorship and recruitment of juveniles to the adult population.

Our results have some obvious applications, as the building of artificial reefs is a common fisheries management tactic used to increase fisheries production in most parts of the world in both freshwater and marine environments (Chou 1988, Gregg 1995, Minton \& Heath 1998, Sinis et al. 2000, Freitas \& Petere 2001, Lok et al. 2002). A range of potential management uses for artificial reefs have been developed since their first documented accounts in Japan in the late 1700s (Meier et al. 1989). They have been used as dive attractions (often in the form of accidental or deliberate ship wrecks), anti-trawling devices (Lok et al. 2002), to increase fish and lobster stocks in fishing areas (Walker et al. 2002), as a tool for the rehabilitation of natural reefs (Clark \& Edwards 1999); to increase primary production in an oligotrophic system (Guiral et al. 1993), to increase fish recruitment to an area (Beets 1989), and to increase local biodiversity. If the aim of a particular artificial reef programme is to increase local fish biodiversity, then optimal artificial reef design should (1) offer a stable substrate in regions where this is unavailable, (2) have a rugose surface with a large number of small refuge holes, and (3) provide a variety of different 'growth forms'.

Acknowledgements. We would like to thank B. Lettsomme, E. Kadison and N. Eristhee of the BVI Department of Conservation and Fisheries for providing a research permit and logistic support. We are grateful to C. Petrovic of the H. Lavity Stoutt Community College, A. Evans and A. Maduro for field assistance, and to the Rhodes Trust for financial support (B.G.). R. Southwood, A. Foggo and N. Brown and 2 anonymous reviewers made helpful comments.

\section{LITERATURE CITED}

August PV (1983) The role of habitat complexity and heterogeneity in structuring tropical mammal communities. Ecology 64:1495-1507

Beck MW (2000) Separating the elements of habitat structure: independent effects of habitat complexity and structural components on rocky intertidal gastropods. J Exp Mar Biol Ecol 249:29-49

Beets JP (1989) Experimental evaluation of fish recruitment to combinations of fish aggregating devices and benthic artificial reefs. Bull Mar Sci 44:973-983

Beukers JS, Jones GP (1997) Habitat complexity modifies the impact of piscivores on a coral reef fish population Oecologia 114:50-59

Borntrager JF, Farrell TM (1992) The effect of artificial reef size on species richness and diversity in a Florida estuary. Fla Sci 55:229-235

Bortone SA, Shipp RL, Davis WP, Nester RD (1988) Artificial reef development along the Atlantic coast of Guatemala. Northeast Gulf Sci 10:45-48

Caley MJ, St John J (1996) Refuge availability structures assemblages of tropical reef fishes. J Anim Ecol 65:414-428

Carpenter RC (1986) Partitioning herbivory and its effects on coral reef algal communities. Ecol Monogr 56:345-364

Carpenter RC (1990) Mass mortality of Diadema antillarum. I. Long-term effects on sea urchin population-dynamics and coral reef algal communities. Mar Biol 104:67-78

Chabanet P, Ralambondrainy H, Amanieu M, Faure G, Galzin R (1997) Relationship between coral reef substrata and fish. Coral Reefs 16:93-102

Chou LM (1988) The commercial and recreational values of artificial reefs. J Singap Natl Acad Sci 17:50-52

Clark S, Edwards AJ (1999) An evaluation of artificial reef structures as tools of marine habitat rehabilitation in the Maldives. Aquat Conserv 9:5-21

Cohen AS, Bills R, Cocquyt CZ, Caljon AG (1993) The impact of sediment pollution on biodiversity in Lake Tanganyika. Conserv Biol 7:667-677

Dahl AL (1973) Surface area in ecological analysis: quantification of benthic coral-reef algae. Mar Biol 23:239-249

Davidowitz G, Rosenzweig ML (1998) The latitudinal gradient of species diversity among North American grasshoppers (Acrididae) within a single habitat: a test of the spatial heterogeneity hypothesis (in animal patterns). J Biogeogr 25:553-560

Diamant A, Ben TA, Baranes A, Golani D (1986) An analysis of rocky coastal eastern Mediterranean fish assemblages and a comparison with an adjacent small artificial reef. J Exp Mar Biol Ecol 97:269 286

Dueser RD, Brown WC (1980) Ecological correlates of insular rodent diversity. Ecology 61:50-56

Ferreira CEL, Goncalves JEA, Coutinho R (2001) Community structure of fishes and habitat complexity on a tropical rocky shore. Environ Biol Fish 61:353-369

Finch DM (1989) Habitat use and habitat overlap of riparian birds in three elevational zones. Ecology 70:866-880

Foster SA (1985) Size-dependent territory defense by a damselfish Stegastes dorsopunicans a determinant of resource use by group-foraging surgeonfishes. Oecologia 67:499-505

Freitas CE, Petere M (2001) Influence of artificial reefs on fish assemblage of the Barra Bonita Reservoir (Sao Paulo, Brazil). Lakes Reserv Res Manag 6:273-278

Gilinsky E (1984) The role of fish predation and spatial heterogeneity in determining benthic community structure. Ecology 65:455-468

Gorham JC, Alevizon WS (1989) Habitat complexity and the abundance of juvenile fishes residing on small scale artificial reefs. Bull Mar Sci 44:662-665

Gorman OT, Karr JR (1978) Habitat structure and stream fish communities. Ecology 59:507-515

Gregg KL (1995) Comparisons of three manufactured artificial reef units in Onslow Bay, North Carolina. N Am J Fish Manag 15:316-324

Guidetti P (2000) Differences among fish assemblages associated with nearshore Posidonia oceanica seagrass beds, rocky-algal reefs and unvegetated sand habitats in the Adriatic Sea. Estuar Coast Shelf Sci 50:515 529

Guiral D, Arfi R, Da KP, Konan BAA (1993) Algal communities, biomasses and productions in an artificial reef 
(Acadja) built in a brackish tropical lagoon. Rev Hydrobiol Trop 26:219-228

Harding EK (2003) Scientism as a barrier to our progress. Conserv Biol 17:651

Harding JM, Mann R (2001) Oyster reefs as fish habitat: opportunistic use of restored reefs by transient fishes. J Shellfish Res 20:951-959

Hartney KB, Grorud KA (2002) The effect of sea urchins as biogenic structures on the local abundance of temperate reef fish. Oecologia 131:506-513

Haslett JR (1997) Insect communities and the spatial complexity of mountain habitats. Global Ecol Biogeogr Lett 6: $49-56$

Hay ME, Taylor PR (1985) Competition between herbivorous fishes and urchins on Caribbean reefs. Oecologia 65:591-598

Heck KL Jr, Wetstone GS (1977) Habitat complexity and invertebrate species richness and abundance in tropical seagrass meadows. J Biogeogr 4:135-142

Heise RJ, Bortone SA (1999) Estuarine artificial reefs to enhance seagrass planting and provide fish habitat. Gulf Mex Sci 17:59-74

Hixon MA, Beets JP (1993) Predation, prey refuges, and the structure of coral-reef fish assemblages. Ecol Monogr 63: 77-101

Horan DL, Kershner JL, Hawkins CP, Crowl TA (2000) Effects of habitat area and complexity on Colorado River cutthroat trout density in Uinta mountain streams. Transac Am Fish Soc 129:1250-1263

Hull SL (1997) Seasonal changes in diversity and abundance of ostracods on four species of intertidal algae with differing structural complexity. Mar Ecol Prog Ser 161:71-82

Humann P (1994) Reef fish identification. New World Publications, Jacksonville, FL

Jennings S, Boulle DP, Polunin NVC (1996) Habitat correlates of the distribution and biomass of Seychelles reef fishes. Environ Biol Fish 46:15-25

Kellison GT, Sedberry GR (1998) The effects of artificial reef vertical profile and hole diameter on fishes off South Carolina. Bull Mar Sci 62:763-780

Khalaf MA, Kochzius M (2002) Community structure and biogeography of shore fishes in the Gulf of Aqaba, Red Sea. Helgol Meeresunters 55:252 284

Kohn AJ (1967) Environmental complexity and species diversity in the gastropod genus Conus on Indo-West Pacific reef platforms. Am Nat 101:251-259

Lok A, Metin C, Ulas A, Duzbastilar FO, Tokac A (2002) Artificial reefs in Turkey. ICES J Mar Sci 59:S192-S195

Luckhurst BE, Luckhurst K (1978) Analysis of the influence of substrate variables on coral reef fish communities. Mar Biol 49:317-323

MacArthur RH, MacArthur JW (1961) On bird species diversity. Ecology 42:594-598

Magnus DBE (1967) Ecological and ethological studies and experiments on the echinoderms of the Red Sea. Stud Trop Oceanogr 5:635-664

McClanahan TR (1994) Kenyan coral reef lagoon fish: effects of fishing, substrate complexity, and sea urchins. Coral Reefs 13:231-241

Meier MH, Buckley R, Polovina JJ (1989) A debate on responsible artificial reef development. Bull Mar Sci 44: 1051-1057

Minton RV, Heath SR (1998) Alabama's artificial reef program: building oases in the desert. Gulf Mex Sci 16:105-106

Editorial responsibility: Otto Kinne (Editor-in-Chief), Oldendorf/Luhe, Germany
Molles MC (1978) Fish species diversity on model and natural reef patches: experimental insular biogeography. Ecol Monogr 48:289-305

Nagelkerken I, Roberts CM, van der Velde G, Dorenbosch M, Riel MC, Cocheret de la Moriniere E, Nienhuis PH (2002) How important are mangroves and seagrass beds for coral-reef fish? The nursery hypothesis tested on an island scale. Mar Ecol Prog Ser 244:299-305

Ogden JC, Gladfelter EH (1983) Coral reefs, seagrass beds, and mangroves: their interaction in the coastal zones of the Caribbean. UNESCO Rep Mar Sci 23

Ohman MC, Rajasuriya A (1998) Relationships between habitat structure and fish communities on coral and sandstone reefs. Environ Biol Fish 53:19-31

Pianka ER (1966) Convexity, desert lizards and spatial heterogeneity. Ecology 47:1055-1059

Pianka ER (1973) The structure of lizard communities. Annu Rev Ecol Syst 4:53-74

Randall JE (1965) Grazing effect on sea grasses by herbivorous reef fishes in the West Indies. Ecology 46:255-260

Randall JE, Schroeder RE, Starck WA (1964) Notes on the biology of the echinoid Diadema antillarum. Caribb J Sci 4:421-433

Rilov G, Benayahu Y (1998) Vertical artificial structures as an alternative habitat for coral reef fishes in disturbed environments. Mar Environ Res 45:431-451

Rilov G, Benayahu Y (2002) Rehabilitation of coral reef-fish communities: the importance of artificial-reef relief to recruitment rates. Bull Mar Sci 70:185-197

Risk MJ (1972) Fish diversity on a coral reef in the Virgin Islands. Atoll Res Bull 153:1-6

Roberts CM, Ormond RFG (1987) Habitat complexity and coral reef fish diversity and abundance on Red Sea fringing reefs. Mar Ecol Prog Ser 41:1-8

Robertson DR (1991) Increases in surgeonfish populations after mass mortality of the sea urchin Diadema antillarum in Panama indicate food limitation. Mar Biol 111:437-444

Santos MN, Monteiro CC (1998) Comparison of the catch and fishing yield from an artificial reef system and neighbouring areas off Faro (Algarve, south Portugal). Fish Res 39:55-65

Simberloff D (1972) Properties of the rarefaction diversity measurement. Am Nat 106:414-418

Sinis AI, Chintiroglou CC, Stergiou KI (2000) Preliminary results from the establishment of experimental artificial reefs in the N. Aegean Sea (Chalkidiki, Greece). Belg J Zool 130:143-147

Southwood TRE, Brown VK, Reader PM (1979) The relationships of plant and insect diversities in succession. Biol J Linn Soc 12:327-348

Telleria JL, Carrascal LM (1994) Weight-density relationships between and within bird communities: implications of niche space and vegetation structure. Am Nat 143: 1083-1092

Valles H (2001) Larval supply to a marine reserve and adjacent fished area in the Soufriere Marine Management Area, St Lucia, West Indies. J Fish Biol 59:152-177

Walker BK, Henderson B, Spieler RE (2002) Fish assemblages associated with artificial reefs of concrete aggregates or quarry stone offshore Miami Beach, Florida, USA. Aquat Living Resour 15:95-105

Williams SE, Marsh H, Winter J (2002) Spatial scale, species diversity, and habitat structure: small mammals in Australian tropical rain forest. Ecology 83:1317-1329

Submitted: April 20, 2004; Accepted: January 13, 2005

Proofs received from author(s): April 18, 2005 